\title{
ASSESSMENT OF CIRCULATING MCP-1 LEVEL AND 2518A>G GENE POLYMORPHISM IN SYSTEMIC LUPUS ERYTHEMATOSUS
}

\author{
AVALIAÇÃO DO NÍVEL CIRCULANTE DE MCP-1 E POLIMORFISMO DO GENE \\ 2518A>G NO LÚPUS ERITEMATOSO SISTÊMICO
}

\author{
Phebe Lotfy ABDEL-MESSEIH ${ }^{1}$; Hussein S. EL-FISHAWY ${ }^{2}$; \\ Abeer Mohamed Ahmed ZAHRAN ${ }^{3}$; Noha Mahmoud Abdel BAKI ${ }^{3}$ \\ 1. Assistant Professor of clinical and chemical pathology, Health Radiation Research Dept., National Center for Radiation Research and \\ Technology - Atomic Energy Authority - Cairo, Egypt. febylotfy@yahoo.com; 2. Assistant Professor of Internal Medicine - Faculty of \\ Medicine, Cairo University; 3. Lecturer of Rheumatology and Rehabilitation, Faculty of Medicine, Cairo, University
}

ABSTRACT: Lupus nephritis (LN) is a major contributor to morbidity and mortality in patients with Systemic Lupus Erythematosus (SLE). This study aims to investigate the possible role of a functional polymorphism in the regulatory region of the monocyte chemo-attractant protein-1 (MCP-1) gene and MCP-1 blood level in the diagnosis of LN and in correlating the MCP-1 blood levels with disease activity. The study included 56 SLE patients and 56 controls. All the SLE patients suffered from LN. An analysis of MCP-1 gene polymorphism by polymerase chain reaction was performed followed by restriction fragment length polymorphism (PCR-RFLP) analysis and MCP-1 blood level was determined using the ELISA technique. Calculation of Systemic Lupus Erythematosus Disease Activity Index (SLEDAI) was performed. Serologic tests included the determination of antinuclear antibody (ANA) and anti-double-stranded (ds) DNA antibodies, Complement $\mathrm{C} 3$ and $\mathrm{C} 4$ levels. A significant increase in the frequency of genotype $\mathrm{A} / \mathrm{G}$ and a decrease in the frequency of genotype A/A were found among patients with active LN compared to inactive LN. There was a statistically significant difference in the blood level of MCP-1 between LN patients and controls. Also, MCP-1 blood levels were significantly higher in active LN patients than inactive LN. A significant positive linear correlation was detected between MCP-1 blood level and SLEDAI, creatinine, and 24 hours protein in LN patients. These results suggest that an $\mathrm{A} / \mathrm{G}$ genotype together with the measurement of the blood level of MCP1 can be a useful tool for detection and follow up of active LN.

KEYWORDS: SLE. LN. MCP-1. Gene polymorphism.

\section{INTRODUCTION}

Systemic Lupus Erythematosus (SLE) is a progressive autoimmune disease due to chronic stimulation of various components of the immune system affecting the skin, joints, kidneys, heart, and nervous system. The etiology of SLE is unknown, and the clinical course is highly variable (DE LEEUW et al., 2006).

The assessment of disease activity in patients affected by SLE is an extremely important issue. However, there is no golden standard to measure disease activity in patients affected by SLE (CECCARELLI et al., 2015). The assessment of SLE patients in routine clinical practice is mainly based on the experience of the treating physician; consequently, this carries a risk of unwanted variability that may have an impact on outcomes. Activity categories have been defined on the basis of Systemic Lupus Erythematosus Disease Activity Index (SLEDAI) scores: no activity (SLEDAI $=1$ to 5), moderate activity (SLEDAI $=6$ to 10), high activity (SLEDAI $=11$ to 19$)$ and very high activity (SLEDAI > 20) (MOSCA et al., 2011).

Renal involvement in SLE conveys significant morbidity and mortality. Over half of all SLE patients will develop lupus nephritis (MUNROE and JAMES, 2016). Lupus nephritis (LN) demonstrates a wide range of glomerular alterations. The predicTablelaboratory markers used in clinical practice as serum complement levels and ds-DNA antibodies are undependable indicators of LN since they lack both sensitivity and specificity for the expectation of active or relapsing LN. Moreover, other laboratory tests such as proteinuria, urinary sediments, and serum creatinine are nonspecific and unsatisfactory markers, as significant renal damage can occur before they rise (BRUNNER et al., 2006). Renal biopsy remains the gold standard for the assessment of LN disease activity. However, it is an aggressive procedure and serial renal biopsies are not suiTablein clinical practice. Therefore, it is very important to identify noninvasive novel biomarkers that are able to expect renal flares and/or reflect its activity. Clinical 
parameters are not sensitive or specific enough for detecting ongoing disease activity in the SLE (GHOBRIAL et al., 2015). Genetic association studies have identified more than 50 polymorphisms that contribute to $\mathrm{LN}$ pathogenesis (MUNROE; JAMES, 2016).

Monocyte Chemoattractant Protein-1(MCP1) promotes the recruitment of monocytes, macrophages, and other inflammatory cells to inflammation sites by interaction with the specific $\mathrm{C}-\mathrm{C}$ chemokine receptor type 2 (CCR2) (MANDAL et al., 2015). Monocytes and macrophages are key components of the innate system. They can secrete a wide range of cytokines and chemokines which can stimulate and recruit the immune response. A large amount of evidence suggests a causal link between the presence and activation of these cells and the development of autoimmune diseases (MA et al., 2019). An A to $G$ single nucleotide polymorphism (SNP) in the MCP-1enhancer region originally designated as $-2518 \mathrm{G}$ may modulate the levels of MCP-1 expression. The MCP-1 -2518G allele is linked with increased production of both MCP-1 transcript and protein (PITROWSKI et al., 2010). The $-2518 \mathrm{~A} / \mathrm{G}$ gene polymorphism was found to be responsible for elevated levels of $\mathrm{MCP}-1$ produced by monocytes in response to inflammation. This is documented to occur with chronic inflammatory conditions as autoimmune diseases, atherosclerosis, and chronic infectious diseases (COLOBRAN et al., 2007; MASSELLI et al., 2018).

Involvement of the MCP-1 $-2518 \mathrm{~A} / \mathrm{G}$ promoter polymorphism in SLE development and its contribution to some clinical manifestations of SLE remains controversial (BROWN et al., 2007). Till now only a few studies have investigated the association of MCP-1-2518 A/G with LN susceptibility but the results have been inconsistent.

The present study aimed to estimate the serum MCP-1 level and -2518A $\backslash \mathrm{G}$ polymorphism in lupus nephritis patients in order to highlight their possible role in the diagnosis of Lupus nephritis and correlate the MCP-1 blood levels with disease activity and renal status.

\section{MATERIAL AND METHODS}

A case-control study including 56 patients with systemic Lupus Erythematosus (SLE) from those attending the rheumatology department, faculty of medicine, Cairo University in the period from June 2017 to October 2018 was categorized as SLE patients by fulfilling the criteria of American College of Rheumatology (ACR). All patients had biopsy-proven Lupus Nephritis (LN). Exclusion criteria: Subjects with chronic renal insufficiency, chronic dialysis patients, uncontrolled hypertension, chronic infections, ongoing malignancy, pregnancy, and diabetes were excluded from the study.

The patients were divided into two groups based on LN activity. Active LN patients $(n=20)$ defined by one or more of the following criteria: First, proteinuria more than $1 \mathrm{~g} /$ day with or without hematuria or an increase in serum creatinine. Second, renal SLEDAI $\geq 4$ (out of 16) (GLADMAN1 et al., 2002). Inactive $\mathrm{LN}(\mathrm{n}=36)$ defined by one or more of the following criteria: First, proteinuria less than $0.5 \mathrm{~g} /$ day with or without inactive urine sediment and sTableserum creatinine. Second, renal SLEDAI was zero or less than 4 (out of 16) (KONG, 2010). The control group consisted of 56 healthy individuals. They underwent their routine visit at the preventive health care services on the same day as the patients' clinic visit.

Clinical examination and careful history were taken with emphasis on symptoms and signs of SLE and LN. Biopsy results were available for classifying patients according to the grade of nephritis (G1-G5).

All procedures were performed according to the ethical standards of the institutional and national research committee stated in the Helsinki declaration of 1964 as amended in 2013. Written informed consent of participation in the study was taken from all participants.

Laboratory methods were done for the assessment of SLEDAI and Renal SLEDAI to determine LN activity and designate patients into active or inactive LN groups. Laboratory investigations performed included: serum creatinine, blood urea, serum albumin, 24 hours protein in the urine. Complete urine analysis for the presence of red blood cells (RBCs), pus cells, albumin, and urinary casts (either granular, hyaline, tubular, and/or mixed type) were carried out for SLEDAI calculation. Serologic tests included: Antinuclear antibody (ANA) and anti-dsDNA that were detected by indirect immunofluorescent assay provided by immunodiagnostics. Complement $\mathrm{C} 3$ and $\mathrm{C} 4$ were determined by single radial immune-diffusion plates.

\section{Estimation of MCP-1 blood levels and DNA isolation for MCP-1 genotyping: \\ MCP-1 blood levels were determined using} Human RayBio ELISA kit, ELH-MCP-1 provided by Ray Biotech ISO 13485 certified. The mentioned kit is an in vitro enzyme-linked immunosorbent assay for the quantitative measurement of human MCP-1 in serum. 
DNA isolation and genotyping: Genomic DNA was extracted from the peripheral leukocytes obtained from EDTA-treated whole blood, using Sigma thermo-scientific spin columns that provide protein desalting and recovery in a centrifuge format according to the manufacturer's instructions.

MCP-1 promotor gene mutation was detected by polymerase chain reaction followed by restriction enzyme-fragment analysis (PCR-RFLP). For the detection of $-2518 \mathrm{~A} / \mathrm{G}$ mutation, specific primers and restriction endonucleases were used. The following primers were used for amplification. Forward primer: $5^{-}$CCGAGATGTTC CCAGCACAG- $3^{-}$and reverse primer: $5^{-}$ CTGCTTTGCTT GT GCCTCTT-3- supplied by Thermo Scientific. The amplified product was digested with a Fast Digest restriction enzyme that recognizes the $\mathrm{CAG}^{\wedge} \mathrm{CTG}$ site and cuts best at $37^{\circ} \mathrm{C}$ in 15 minutes using a FastDigest Thermo Scientific Pvull. The amplification products were separated by electrophoresis and 100 base pair ladders were used for detection.

If the MCP-1-2518-A allele mentioned remains uncut, it is designated as a single 930-bp band and identified as A/A (normal type). Samples having mutations were either: samples with three bands of 930, 708, and $222 \mathrm{bp}$ that were typed as $\mathrm{A} / \mathrm{G}$ (heterozygous for the mutation), and those with two bands of 708 and 222 bp were typed as $\mathrm{G} / \mathrm{G}$ (homozygous for the mutation).

Statistical analysis: Genotype analysis was performed using Fisher's exact test. The results were expressed as Mean \pm Standard Deviation. The statistical difference between groups was analyzed using the Student's $t$-test. Pearson's correlation analysis was performed to determine the relations between variables. The results were considered significant at $P<0.05$. The statistical calculations were done using the Statistical Package for the Social Sciences software - version 15, while the presentations were performed using Microsoft Excel 2007.

\section{RESULTS}

Comparing the results obtained for healthy controls with those obtained for SLE patients having $\mathrm{LN}$, it was observed that there was no statistically significant difference in the distribution of the individual MCP-1 genotypes between LN and controls. There was a statistically significant difference in the blood level of MCP-1 between LN of patients and controls. It was found that $39.28 \%$ of LN patients were grade 3 (G3), 39.28\% were grade
4 (G4) and $21.42 \%$ were grade 5 (G5) as shown in Table1.

However, the comparison between active LN patients $(n=20)$ with inactive LN $(n=36)$ revealed that active $\mathrm{LN}$ patients more commonly have the $\mathrm{A} / \mathrm{G}$ genotype compared to those without active LN. SLE patients with active LN have significantly higher MCP-1 blood levels than inactive $\mathrm{LN}$ as shown in Table2.

In $\mathrm{LN}$ patients and the active LN subgroup, $\mathrm{G}$ allele carriers had significantly higher MCP-1 blood levels compared to A-allele carriers, however, the number of patients with $G$ allele in the inactive LN group was too small to perform a statistical analysis Table3.

A significant positive linear correlation was detected between MCP-1 blood level and SLEDAI, creatinine, and 24 hours protein in lupus nephritis patients Table4. 
Table 1. Demographic, Clinical, Laboratory Data and Genotype Analysis of the studied groups

\begin{tabular}{|c|c|c|c|}
\hline Characteristics & LN patients $n=56$ & Controls $n=56$ & P-value \\
\hline Sex (male/female) & $6 / 50$ & $7 / 49$ & $>0.05$ \\
\hline Age in years & $30.25 \pm 9.55$ & $31.36 \pm 7.99$ & $>0.05$ \\
\hline Duration & $6.46 \pm 4.69$ & - & \\
\hline Age at diagnosis & $23.89 \pm 9.54$ & - & \\
\hline Nephritis & $100 \%$ & - & \\
\hline Hematuria & $57 \%$ & $0 \%$ & \\
\hline Pyuria & $57.1 \%$ & $0 \%$ & \\
\hline Urinary cast & $17.9 \%$ & $0 \%$ & \\
\hline Proteinuria & $71.4 \%$ & $0 \%$ & \\
\hline Arthritis & $7.1 \%$ & $0 \%$ & \\
\hline ANA +ve & $100 \%$ & $0 \%$ & \\
\hline Anti-ds DNA+ve & $67.9 \%$ & $0 \%$ & \\
\hline Vasculitis & $7.1 \%$ & $0 \%$ & \\
\hline Thrombocytopenia & $22.2 \%$ & $0 \%$ & \\
\hline Leucopenia & $44.4 \%$ & $0 \%$ & \\
\hline Hemolytic anemia & $48 \%$ & $0 \%$ & \\
\hline $\mathrm{C} 3$ & $77.55 \pm 24.21$ & $110 \pm 20$ & $<0.001$ \\
\hline $\mathrm{C} 4$ & $12.30 \pm 6.49$ & $20 \pm 5$ & $<0.001$ \\
\hline SLEDAI & $8.04 \pm 6.91$ & 0 & \\
\hline Renal SLEDAI & $2.21 \pm 0.9$ & 0 & \\
\hline Urea $(\mathrm{mmol} / \mathrm{L})$ & $17.57 \pm 19.0$ & $10.7 \pm 3.57$ & $<0.05$ \\
\hline Creatinine $(\mu \mathrm{mol} / \mathrm{L})$ & $112.26 \pm 128.18$ & $88.4 \pm 35.36$ & $>0.05$ \\
\hline Albumin & $3.33 \pm 0.66$ & $4 \pm 0.5$ & $<0.001$ \\
\hline 24 Hours protein (g/day) & $1.56 \pm 1.54$ & $0.1 \pm 0.01$ & $<0.001$ \\
\hline MCP-1 blood level & $255.93 \pm 176.93$ & $29.20 \pm 30.01$ & $<0.001$ \\
\hline Biopsy grade G3or less & $22(39.28 \%)$ & & \\
\hline Grade 4 & $22(39.28 \%)$ & & \\
\hline Grade 5 & $12(21.42 \%)$ & & \\
\hline MCP-1 genotype AA & $39(69.6 \%)$ & $44(78.6 \%)$ & $>0.05$ \\
\hline MCP-1 genotype AG/GG & $17(30.4 \%)$ & $12(21.4 \%)$ & $>0.05$ \\
\hline Allele A & $94(83.9 \%)$ & $100(89.3 \%)$ & $>0.05$ \\
\hline Allele G & $18(16.1 \%)$ & $12(10.7 \%)$ & $>0.05$ \\
\hline
\end{tabular}

*P values $>0.05$ means non-significant changes, $\mathrm{P}$ values $<0.05$ means statistically significant, $\mathrm{P}$ values $<0.01$ or 0.001 means highly significant changes. All results are expressed as Mean \pm Standard Deviation. 
Assessment of circulating...

ABDEL-MESSEIH, P. L. et al

Table 2. Clinical and Laboratory Data of the Active Lupus nephritis (LN) compared to Inactive LN Patients

\begin{tabular}{cccc}
\hline Characteristics & $\begin{array}{c}\text { Active LN patients } \\
\mathbf{n = 2 0}\end{array}$ & $\begin{array}{c}\text { Inactive LN patients } \\
\mathbf{n = 3 6}\end{array}$ & P values \\
\hline C3 & $62.26 \pm 25.63$ & $86.04 \pm 19.21$ & $<0.01$ \\
C4 & $13.40 \pm 7.33$ & $13.4 \pm 7.33$ & $>0.05$ \\
SLEDAI & $15.60 \pm 5.64$ & $3.83 \pm 2.57$ & $<0.01$ \\
Renal SLEDAI & $4.21 \pm 1.2$ & $1.3 \pm 0.5$ & $<0.01$ \\
Urea (mmol/L) & $21.86 \pm 29.70$ & $15.19 \pm 9.74$ & $>0.05$ \\
Creatinine ( $\mu$ mol/L) & $159.12 \pm 203.32$ & $85.75 \pm 48.62$ & $>0.05$ \\
Albumin (g/dl) & $3.16 \pm 0.70$ & $3.63 \pm 0.43$ & $>0.05$ \\
24 Hours protein(g/day) & $2.19 \pm 1.59$ & $0.42 \pm 0.40$ & $<0.01$ \\
MCP-1 blood level & $437.70 \pm 186.73$ & $154.94 \pm 31.98$ & $<0.01$ \\
MCP-1 genotype AA & $4(20 \%)$ & $35(97.2 \%)$ & $<0.001$ \\
MCP-1 genotype AG/GG & $16(80 \%)$ & $1(2.78 \%)$ & $<0.001$ \\
Allele A & $23(57.5 \%)$ & $71(98.6 \%)$ & $<0.001$ \\
Allele G & $17(42.5 \%)$ & $1(1.4 \%)$ & $<0.001$ \\
\hline
\end{tabular}

*P values $>0.05$ means non-significant changes, $\mathrm{P}$ values $<0.05$ means statistically significant, $\mathrm{P}$ values $<0.01$ or 0.001 means highly significant changes. All results are expressed as Mean \pm Standard Deviation.

Table 3. The blood level of Monocyte Chemo-attractant Protein-1 (MCP-1) (mg/L) in different genotypes in the Lupus nephritis (LN) patients.

\begin{tabular}{lccc}
\hline MCP-1 blood level & $\begin{array}{c}\text { Genotype } \\
\text { A/A }\end{array}$ & $\begin{array}{c}\text { Genotype } \\
\text { A/G or G/G }\end{array}$ & P values \\
\hline LN patients & $163.2 \pm 39.87$ & $487.75 \pm 174.47$ & $<0.0001$ \\
Active LN & $200.33 \pm 20.5$ & $461.78 \pm 108.85$ & $<0.05$ \\
\hline
\end{tabular}

Table 4. The Association of Monocyte Chemo-attractant Protein-1 (MCP-1) (mg/L) blood level with clinical and laboratory manifestations in Systemic Lupus Erythematosus (SLE) patients suffering from Lupus nephritis (LN).

$\begin{array}{ccc}\text { Characteristic variable } & \begin{array}{c}\text { Pearson correlation } \\ \text { P values }\end{array} & \text { Sig. } \\ \text { SLEDAI } & \text { R 0.958, P 0.000 } & \text { Sig +ve } \\ \text { C3 } & \text { R - 0.544, P 0.003 } & \text { Sig-ve } \\ \text { Albumin } & \text { R - 0.508, P 0.006 } & \text { Sig -ve } \\ \text { Creatinine } & \text { R 0.401, P 0.034 } & \text { Sig +ve } \\ 24 \text { hours protein } & \text { R 0.425, P } 0.024 & \text { Sig +ve }\end{array}$

\section{DISCUSSION}

SLE is an autoimmune disease under genetic control (XUE et al., 2018). MCP-1 has been proposed as the main chemokine responsible for initiating autoimmune tissue damage. MCP-1 -2518 $\mathrm{A}>\mathrm{G}$ polymorphism has been associated with ocular
Behçet's disease, adult and juvenile type of rheumatoid arthritis, systemic sclerosis, and psoriasis (HOU et al., 2010). Reports on the contribution of the MCP-1 $-2518 \quad A>G$ polymorphism to SLE incidence and clinical manifestations have been inconsistent. 
Assessment of circulating...

$\mathrm{LN}$ is a severe and frequent manifestation of SLE. Early detection of initial renal manifestations and relapses during follow up is important to prevent loss of renal function (DOLFF et al., 2013). Active LN especially early flares often respond to proper treatment with immunosuppressive drugs. However, these drugs are themselves associated with significant morbidity and even mortality, whilst uncontrolled LN activity leads to chronic, end-stage kidney disease (ESRD) or even death. Current standard laboratory markers such as proteinuria cannot always distinguish between active and inactive renal disease especially in patients with a recent history of LN (BALOW, 2005).

The role of MCP-1 gene polymorphism in SLE has been investigated in a few studies yet with variable and contradictory results. The reasons for the variability are still unclear (MOHAMMAD et al., 2015). The $-2518 \mathrm{~A} / \mathrm{G}$ gene polymorphism was found to be responsible for elevated levels of MCP1 produced by monocytes in response to inflammation in some autoimmune diseases. Therefore, this case-control study was conducted to evaluate the role of $-2518 \mathrm{~A} / \mathrm{G}$ polymorphism in LN.

High levels of MCP-1 were demonstrated in the blood of patients with LN in the present study. A study conducted by ZIVKOVIC et al., 2018 showed that serum MCP-1 had a high SLE specificity (90\%) and that its level was significantly higher in SLE patients compared to healthy controls regardless of disease activity. This was consistent with the results of MOHAMMAD et al., 2015 which demonstrated significantly elevated MCP-1 blood levels in LN patients compared to the controls. This suggests an important role of circulating MCP-1 in SLE patients with renal damage.

In the current study, there was no significant increase in $\mathrm{MCP}-1$ gene polymorphism $(\mathrm{G} / \mathrm{G}$ or $\mathrm{A} / \mathrm{G})$ in SLE Egyptian patients with LN compared to the controls. AGUILAR et al. (2001), also did not find any association between the $-2518 \mathrm{~A} / \mathrm{G}$ MCP-1 polymorphism and the susceptibility to SLE nor with the presence of $\mathrm{LN}$. This is consistent with PITROWSKI et al. (2010) who did not observe significant differences in the prevalence of MCP-1$2518 \mathrm{~A}>\mathrm{G}$ polymorphism or $\mathrm{G} / \mathrm{G}$ or $\mathrm{A} / \mathrm{G}$ alleles in patients with SLE compared to controls in the Polish and Caucasian populations (PITROWSKI et al., 2010). Also, previous results of MCP-1gene polymorphism contribution to SLE incidence in African, American, Spanish, Korean, and Mexican patients did not report any significant contribution.
ABDEL-MESSEIH, P. L. et al

The discrepancy between elevated MCP-1 blood levels in LN in the absence of a significant increase in $\mathrm{G} / \mathrm{G}$ or $\mathrm{A} / \mathrm{G}$ genotype may be due to the genetic background of the various ethnic populations and the environmental exposure. This disparity may also have resulted from each population's exposure to distinct environmental factors, which may act in synergy with the MCP-1 $2518 \mathrm{~A}>\mathrm{G}$ polymorphism to change the risk of SLE incidence among the studied populations (JONSEN et al., 2007). The pathogenesis of LN has many aspects and is regulated by many genes and signals. The analysis of a single nucleotide variation may not be able to elucidate the genetic association of LN.

There are conflicting results in the literature regarding the association of $\mathrm{A} / \mathrm{G}$ polymorphism with LN. This may be due to differences in the racial heterogeneity of the examined groups. A meta-analysis by SANG et al. (2017) found no significant association between $\mathrm{A} / \mathrm{G}$ polymorphism and LN risk with European and Asian populations but a significant association was found in the American population. However, a meta-analysis by ZHOU et al. (2015) indicated that MCP-1-2518 $A>G$ polymorphism was significantly associated with LN incidence in Caucasian patients. TUCCI et al. (2004) reported that African SLE patients with A/G or G/G MCP-1-2518 genotype had a higher risk of developing LN.

Results of the present study show that SLE patients with active LN have an A/G or G/G MCP-1 -2518 genotype that is significantly higher than those with inactive LN. MOHAMMAD et al. (2015) also reported high $G$ allele frequency among $L N$ patients. The results are in agreement also with studies done by YE et al. (2005) and MOON et al. (2007), who found over-expression of - $2518 \mathrm{G}$ allele in Asian, Mexican, Korean, and Chinese populations with lupus nephritis. Recent data has indicated that genetic polymorphism of MCP-1 may influence the development or progression of the disease (UMARE et al., 2017).

MCP-1 levels are significantly higher in active $\mathrm{LN}$ patients than inactive $\mathrm{LN}$ in the present study. This is in accordance with WATSON et al., (2012) who confirmed that MCP-1 blood levels distinguished between patients with active and inactive lupus nephritis. The MCP-1 -2518G allele was linked with increased production of both MCP1 transcript and protein (PITROWSKI et al., 2010). The $-2518 \mathrm{~A} / \mathrm{G}$ gene polymorphism was found to be responsible for elevated levels of MCP-1 produced by monocytes in response to inflammation. The A/G polymorphism at position -2518 of the MCP-1 gene 
seems to influence the transcriptional activity because cells obtained from individuals GG or AG produce more MCP-1 protein than those isolated from individuals AA (ROVIN and SAXENA, 1999). Consequently, it would be reasonable to speculate that, under the same stimulatory conditions, individuals bearing $\mathrm{G}$ at position -2518 produce more MCP-1 protein than individuals with the genotype AA, and, in consequence, could make a stronger inflammatory response with higher tissue damage. Our results show that in LN patients and the active LN subgroup, $G$ allele carriers have significantly higher MCP-1 blood levels compared to A-allele carriers, which is in accordance with TUCCI et al. (2004) and postulates that $G$ allele carriage may predispose to the development of nephropathy rather than SLE itself. Moreover, PITROWSKI et al. (2010) observed that $\mathrm{G} / \mathrm{G}$ and $\mathrm{A} / \mathrm{G}$ genotypes contributed to renal manifestations of the SLE.

The results of the present study revealed significant positive correlations between MCP-1 blood levels and each of SLEDAI, serum creatinine, and 24 hours protein while correlations with C3 and albumin are significantly negative in the studied LN patients. The significant positive correlations between serum MCP-1 and SLEDAI and between
MCP-1 and serum creatinine in lupus nephritis patients were also observed by MONA ALHOSEINY et al. (2005). TAHA et al. (2019) found a significant positive correlation between 24 hours protein and urinary $\mathrm{MCP}-1$ while a negative correlation was found with $\mathrm{C} 3$ in active $\mathrm{LN}$ patients. The present study implicates the possible role of circulating MCP-1 and its $-2518 \mathrm{~A} / \mathrm{G}$ polymorphism as a valuable marker of LN activity in Egyptian SLE patients. Therefore, it would be recommended that the blood level of MCP-1 could be added to the panel of non-invasive biomarkers to identify renal flares.

\section{CONCLUSION}

The MCP-1 -2518 A/G polymorphism is associated with the activity of LN in SLE patients. Patients with $\mathrm{A} / \mathrm{G}$ or $\mathrm{G} / \mathrm{G}$ genotypes have increased MCP-1 production. Screening for MCP-1 polymorphism together with other genetic polymorphisms known to be associated with LN and MCP-1 chemokine together with other chemokines may be applied to determine the relative risk of developing activity in LN patients with an established diagnosis of SLE.

RESUMO: A nefrite do lúpus (LN) é um dos principais contribuintes para a morbidade e mortalidade em pacientes com o Lúpus Eritematoso Sistémico (LES). Este estudo tem como objetivo investigar o possível papel de um polimorfismo funcional na região reguladora do gene da proteína quimioatraente de monócitos-1 (MCP-1) e do nível sanguíneo de MCP-1 no diagnóstico de LN e na correlação do sangue de MCP-1 níveis com atividade da doença. O estudo incluiu 56 pacientes com LES e 56 controles. Todos os pacientes com LES sofriam de LN. Uma análise do polimorfismo do gene MCP-1 por reação em cadeia da polimerase foi realizada seguida pela análise do polimorfismo do comprimento do fragmento de restrição (PCR-RFLP) e o nível sanguíneo do MCP-1 foi determinado pela técnica ELISA. O cálculo do índice de atividade da doença sistêmica do lúpus eritematoso (SLEDAI) foi realizado. Os testes sorológicos incluíram a determinação de anticorpos antinucleares (ANA) e anticorpos anti-DNA de fita dupla (ds), níveis de Complemento C3 e C4. Um aumento significativo na frequência do genótipo $\mathrm{A} / \mathrm{G}$ e uma diminuição na frequência do genótipo $\mathrm{A} / \mathrm{A}$ foram encontrados entre os pacientes com LN ativo em comparação com o LN inativo. Houve uma diferença estatisticamente significante no nível sanguíneo de MCP-1 entre pacientes com LN e controles. Além disso, os níveis sanguíneos de MCP-1 foram significativamente mais altos em pacientes com LN ativo do que com LN inativo. Uma correlação linear positiva significativa foi detectada entre o nível sanguíneo de MCP-1 e SLEDAI, creatinina e proteína de 24 horas em pacientes com LN. Esses resultados sugerem que um genótipo A/G, juntamente com a medição do nível sanguíneo de MCP-1, pode ser uma ferramenta útil para a detecção e acompanhamento do LN ativo.

PALAVRAS-CHAVE: LES. LN. MCP-1. Polimorfismo genético. 


\section{REFERENCES}

AGUILAR, F.; GONZALEZ ESCRIBANO, M.F.; SANCHEZ ROMAN, J.; NUNEZ ROLDAN, A. MCP-1 promoter polymorphism in Spanish patients with systemic lupus erythematosus. Tissue Antigens: v. 58, p. 335-338, 2001. https://doi.org/10.1034/j.1399-0039.2001.580508.x

BALOW, J. E. Clinical presentation and monitoring of lupus nephritis. Lupus, v. 14, n. 1, p. 25-30, 2005. https://doi.org/10.1191/0961203305lu2055oa

BROWN K. S.; NACKOS, E.; MORTHALA, S.; JENSEN, L.E.; WHITEHEAD, A. S; VON FELDT, J. M. Monocyte chemoattractant protein-1: plasma concentrations and A (-2518) G promoter polymorphism of its gene in systemic lupus erythematosus. Journal of Rheumatology, v. 34, n. 4, p. 740-746,2007.

BRUNNER, H.; MUELLER, M.; RUTHERFORD, C.; PASSO, M. H.; WITTE, D.; GROM, A. Urinary neutrophil gelatinase-associated lipocalin as a biomarker of nephritis in childhood-onset systemic lupus erythematosus. Arthritis Rheum, v. 54, p. 2577-84,2006. https://doi.org/10.1002/art.22008

CECCARELLI, F.; PERRICONE, C.; MASSARO, L.; CIPRIANO, E.; ALESSANDRI, C.; SPINELLI, F.R.; VALESININ, G.; CONTI, F. Assessment of disease activity in systemic Lupus Erythematosus: Lights and shadows, Autoimmunity Reviews, v. 14, n. 7,p. 601-608,2015. https://doi.org/10.1016/j.autrev.2015.02.008

COLOBRAN, R.; PUJOL-BORRELL, R.; AYMENGOL, M.P.; JUAN, M. The chemokine network 11. On how polymorphisms and alternative splicing increase the number of molecular species and configure intricate patterns of disease susceptibility. Clin. Exp. Immunol., v. 150, p. 1-12,2007. https://doi.org/10.1111/j.13652249.2007.03489.x

DE LEEUW, K.; FREIRE, B.; SMIT, A. J.; BOOTSMA, H.; KALLENBERG, C. G.; BIJL, M. Traditional, and non-traditional risk factors contribute to the development of accelerated atherosclerosis in patients with SLE. Lupus, v. 15, n. 10, p. 675-682,2006. https://doi.org/10.1177/0961203306069972

DOLFF, S.; ABDULAHAD, W.H.; ARENDS, S.; VAN DIJK, M.C.R.F; LIMBURG, P.C.; KALLENBERG, C.G.M; BIJL, M. Urinary cd8+T cell counts discriminate between active and inactive lupus nephritis. Arthritis Research \& Therapy, v.15, n. 1, R36, p. 1-8,2013. https://doi.org/10.1186/ar4189

GHOBRIAL, E. E.; El HAMSHARY, A. A.; MOHAMED, A. G; ABD El RAHEIM, Y. A.; TALAAT, A. A. Urinary monocyte chemoattractant protein-1 as a biomarker of lupus nephritis activity in children. Saudi J. Kidney Dis. Transpl. v. 26, n. 3, p. 507-15, 2015. https://doi.org/10.4103/1319-2442.157350

GLADMAN, D. D; IBANEZ, D.; UROWLTZ, M. B. Systemic lupus erythematosus disease activity index 2000. Journal of Rheumatology, v. 29, n. 2, p. 288-291, 2002.

HOU, S.; YANG, P.; DU, L. Monocyte chemoattractant protein-1 -2518 A/G single nucleotide polymorphism in Chinese Han patients with ocular Behçet's disease. Human Immunology, v. 71, n. 1, p. 79-82,2010. https://doi.org/10.1016/j.humimm.2009.09.354

JONSEN, A.; BENGTSSON, A.; NIVED, O.; TRUEDSSON, L.; STURFELT, G. Gene-environment interactions in the etiology of systemic lupus erythematosus. Autoimmunity, v. 40, n. 8, p. 613-617, 2007. https://doi.org/10.1080/08916930701511051

KONG, N.C.T. Pulse Cyclophosphamide versus added dual filtration plasmapheresis (DFPP) therapy for severe lupus nephritis. UKM Research Clinical Trial Code (FF-324-2011), 2010.

LIMA, G.; SOTO-VEGA, E.; ATISHA-FREGOSO, Y. MCP-1, RANTES, and SDF-1 polymorphisms in Mexican patients with systemic lupus erythematosus. Human Immunology, v. 68, n. 12, p. 980-985, 2007. https://doi.org/10.1016/j.humimm.2007.10.007 
MA, W.T.; GAO, F.; GU, K.; CHEN, D.-K. The role of monocytes and macrophages in autoimmune diseases: A comprehensive review. Front. Immunol. v. 24, n. 10, p. 1140-1164, 2019.

https://doi.org/10.3389/fimmu.2019.01140

MANDAL, R. K.; AGRAWAL, T.; MITTAL, R. D. Genetic variants of chemokine CCL2 genes and risk of prostate cancer. Tumor Biolo. v. 36, n. 1, p. 375-381, 2015. https://doi.org/10.1007/s 13277-014-2646-X

MASSELli, E.; CARUBBI, C.; CAMBO, B.; POZZI, G.; GOBBI, G.; MIRANDOLA, P.; FOLLINI, E.; PAGLIARO, L.; MARCANTONIO, D.D.; BONATTI, F.; PERCECESEPE, A.; SYKES, S.M.; AVERSA, F.; VITALE, M. The -2518 A/G polymorphism of the monocyte chemoattractant protein-1 as a candidate genetic predisposition factor for secondary myelofibrosis and biomarker of disease severity. Leukemia v. 32, n. 1, p. 2266-2270,2018. https://doi.org/10.1038/s41375-018-0088-y

MOHAMMAD, L.A.; F.D.M.; ABUL-SAOUD, A.M. Association of monocyte chemoattractant protein 1 (MCP-1) gene polymorphism with lupus nephritis in Egyptian patients. Human Immunology, v. 76, n. 10, p. 724-728, 2015. https://doi.org/10.1016/j.humimm.2015.09.027

MONA Al-HOSEINY; Al-HEFNY, A.A.; ABDUL-WAHAB, E.; LOTFI, O.; SALEH, W.; MAHMOUD, H. Serum chemokines in lupus nephritis and SLE disease activity. Egypt Rheumatol., v. 32, n. 2, p. 191$203,2005$.

MOON, J. Y.; JEONG, L.; LEE, S.; JEONG, K.; LEE, T.; IHM, C. G. Association of polymorphisms in monocyte chemoattractant protein -1 promotor with diabetic kidney failure in Korean patients with type 2 diabetes mellitus. J. Korean Med. Sci., v. 22, p. 810-814, 2007. https://doi.org/10.3346/jkms.2007.22.5.810

MOSCA, M.; ARINGER, M.; TANIC, C.; BOMBARDIERI, S.; BOUMPAS, D.; CERVERA, R.; DORA, A.; JAYNE, D.; KHAMASHTA, M.A. Development of quality indicators to evaluate the monitoring of SLE patients in routine clinical practice. Autoimmunity Reviews, v. 10, n. 7, p. 383-288, 2011. https://doi.org/10.1016/j.autrev.2010.12.008

MUNROE, M. E.; JAMES, J. A. Genetics of lupus nephritis: clinical implications. Semin Nephrol., v. 35, n. 5, p. 396-409, 2016. https://doi.org/10.1016/j.semnephrol.2015.08.002

PITROWSKI, P.; LIANERI, M.; GASIK, R.; JAGODZINSKI. Monocyte Chemoattractant Protein-1-2518 A/G Single Nucleotide Polymorphism Might Be Associated with Renal Disease and Thrombocytopenia of SLE. Journal of Biomedicine and Biotechnology, 6 pages, 2010. https://doi.org/10.1155/2010/130265

ROVIN, B.; LU, L.; SAXENA, R. A novel polymorphism in the MCP-1 gene regulatory region that influences MCP-1 expression. Biochem Biophys Res Commun, v. 259, p. 344-348, 1999.

https://doi.org/10.1006/bbrc.1999.0796

SANG, G. Y; MENG, C. R.; H. A. O, Y. F; DAI, J. H. Monocyte chemoattractant protein-1 (MCP-1)-2518 A/G polymorphism and lupus nephritis risk. A PRISMA-compliant meta-analysis. Medicine; v. 96, n. 51, p. e9401-940,2017. https://doi.org/10.1097/MD.0000000000009401

XUE, K.; NIU, W.-Q.; CUI, Y. Association of HLA-DR3 and HLA-DR15 Polymorphisms with the risk of systemic lupus erythematosus. Chin.Med.J. v. 5; n. 23, p. 2844-2851,2018.

TAHA, H. A.; ABDALLAH, N. H.; SALEM, M. N.; HAMOUDA, A. H.; ABD ELAZEEM, M. I.; EESA, N. N. Urinary, and tissue monocyte chemoattractant protein1 (MCP1) in lupus nephritis patients. The Egyptian Rheumatologist, v. 39; p. 145-150, 2017. https://doi.org/10.1016/j.ejr.2017.01.004

TUCCI, M.; BARNES, E. V.; SOBEL, E. S.; CROKER, B. P.; SEGAL, M. S.; REEVES, W. H. O. Strong association of a functional polymorphism in the monocyte chemoattractant protein 1 promotor gene with lupus nephritis. Arthritis Rheum., v. 50, p. 1842-1849,2004. https://doi.org/10.1002/art.20266 
UMARE, V. D.; PRADHAN, V. D.; RAJADHYAKSHA, A. G.; GHOSH, K.; NADKARNI, A. H. A functional SNP MCP-1 (-2518A/G) predispose to renal disorder in Indian systemic lupus erythematosus patients. Cytokine, v. 96, p. 189-194,2017. https://doi.org/10.1016/j.cyto.2017.04.016

WATSON, L.; MIDGLEY, A.; PILKINGTON, C., TULLUS, K.; MARKS, S.; HOLT, R. Urinary monocyte chemoattractant protein 1 and alpha 1 acid glycoprotein as biomarkers of renal disease activity in juvenile-onset systemic lupus erythematosus. Lupus, v. 21, p. 496-501, 2012. https://doi.org/10.1177/0961203311431249 YE, D. Q.; HU, Y. S.; LI, X. P.; YANG, S. C.; HAO, J. H.; HUANG, F. The correlation between monocyte chemoattractant protein -1 and the arthritis of systemic lupus erythematosus among Chinese. Arch. Dermatol. Res., v. 296, p. 366-371, 2005. https://doi.org/10.1007/s00403-004-0531-y

ZHOU, T. B.; JIANG, Z. P.; LIANG, M. J.; HUANG, Y. J. Relation between MCP-1 promotor -2518 A>G gene polymorphism and systemic lupus erythematosus /lupus nephritis. J. Recept. Signal Transduct. Res. v. 35, p. 85-93, 2015. https://doi.org/10.3109/10799893.2014.931433

ŽIVKOVIĆ, V.; CVETKOVIĆ, T.; MITIĆ, B.; STAMENKOVIĆ, B.; STOJANOVIĆ, S.; RADOVANOVIĆDINIĆ, B.; JURIŠIĆ, V. Monocyte chemoattractant protein-1 as a marker of systemic lupus erythematosus: an observational study. Rheumatol Int., v. 38, n. 6, p. 1003-1008,2018. https://doi.org/10.1007/s00296-017-3888$\mathrm{x}$ 